Original Article (short paper)

\title{
The predicting role of perfectionism on team cohesion among Brazilian futsal athletes
}

\author{
José Roberto Andrade do Nascimento Junior ${ }^{1}$ (D), Gabriel Lucas Morais Freire ${ }^{1}$ (D), \\ Adson Alves da Silva ${ }^{1}$ (D), Nathan Leonardo Gomes $\operatorname{Costa}^{1}$ (D), Leonardo de Sousa Fortes ${ }^{2}$ (D), \\ Daniel Vicentini de Oliveira $^{3}$ iD \\ 'Universidade Federal do Vale do São Francisco, Petrolina, PE, Brasil. \\ ${ }^{2}$ Universidade Federal da Paraíba, João Pessoa, PB, Brasil. \\ ${ }^{3}$ Centro Universitário Metropolitano de Maringá, Maringá, PR, Brasil.
}

\begin{abstract}
Aims: This cross-sectional study investigated the predicting role of perfectionism on the perception of team cohesion among futsal athletes. Methods: One hundred and forty of futsal athletes (24.8 \pm 4.9 years) were included who participated of a Brazilian Amateur Cup in 2017. The instruments were Sport Multidimensional Perfectionism Scale-2 and Group Environment Questionnaire. Data analysis was conducted through the Pearson Correlation and Multiple Regression Analysis $(\mathrm{p}<.05)$. Results: The data showed the following significant correlations $(\mathrm{p}<.05)$ : Group-Integration Task (GI-T) with Organization-Personal Standards (OPS) $(r=.27)$ and Doubts About Action (DAA) $(r=-.24)$; Group-Integration Social (GI-S) with OPS $(r=.18)$; Individual Attraction to Group-Task (IA-T) with OPS $(r=.25)$; Individual Attraction to the Group-Social (IA-S) with OPS $(r=.17)$. Multiple regression showed that OPS showed a positive association with task cohesion dimensions (GI-T and IA-T), while DAA showed a negative association with both social (GI-S and IA-S) and task (GI-T) cohesion. Further, perceived parental pressure showed positive association with GI-S. Conclusion: our findings show that perfectionistic striving could be a positive predictor of task cohesion, while perfectionistic concerns might predict negatively both social and task cohesion.
\end{abstract}

Keywords: perfectionistic, team cohesion, futsal, group environment, sport.

\section{Introduction}

Soccer and futsal are the most popular sports in Brazil ${ }^{1,2}$. These sports are characterized as invasion sport that has simultaneous participation of two teams in a common space and presents particularities that reveal the strong appeal to the physical, technical, tactical and psychological levels of the players ${ }^{3-5}$. Among the psychological attributes, athletes' personality has been pointed out as a predictive factor for positive behaviors, which may enhance individual and team performance ${ }^{6}$.

One of the personality traits that has received great attention from sport psychology researchers is perfectionism $^{7,8}$. Perfectionism is characterized as a multidimensional trait related to the individual's desire to achieve a high standard of performance accompanied by a critical tendency towards their performance ${ }^{8-11}$. In this perspective, the conceptual model developed by Stoeber and $\mathrm{Otto}^{12}$ indicates the need to differentiate perfectionism into two major dimensions: perfectionistic concern and perfectionistic striving ${ }^{8,10,13}$.

On one hand, perfectionistic concerns (PC) correspond to high demand for concerns about mistakes, doubts about actions, socially prescribed criteria, and an exces- sive discrepancy between real performance and high standards ${ }^{14}$. It has been associated with the frustration of meeting basic psychological needs ${ }^{15}$, negative emotional responses ${ }^{14}$, motivation ${ }^{13,16,17}$; burnout $^{18}$ and pre-competitive anxiety ${ }^{19}$. On the other hand, perfectionistic striving (PS) involves high standards of personal fulfillment for excellence that has been associated with the athlete's performance optimization, intrinsic motivation, team cohesion and emotions (self-confidence) 17,20-22 $^{17}$.

Although PC and PS have been considered to play a significant role in athletes' cognitive, affective and behavioral experiences in several researches ${ }^{8,10,13,23,24}$, few studies have tried to understand their effect on team processes, especially athletes' perceived team cohesion, which is known to be a key element to sports performance $^{25-28}$.

According to the Carron, Widmeyer and Brawley ${ }^{29}$ conceptual framework, team cohesion is a group dynamic variable that assesses team's members who work toward a common goal and everyone's responsibility. The literature states that cohesion can be comprehended as a 2-axis concept, the subject and environment levels. Subject level refers to the team as a whole and how the team's member achieves their personal needs and goals and is a key factor 
for the team union. At the environment level, cohesion has been divided into task-related or social-related aspects $^{26-28,30,31}$.

The literature demonstrates that perfectionism can be considered one of the key factors for a high level of team cohesion and performance ${ }^{32,33}$. Specifically, previous study reported an association between perfectionism and athletes' perception about team cohesion among Brazilian futsal players, demonstrating that athletes with greater perfectionistic striving perceived greater both social and task cohesion ${ }^{34}$. Another study investigated the effect of perfectionism traits on team cohesion among elite futsal athletes, showing that within the Brazilian futsal context, adaptive perfectionism seems to promote a positive impact on team cohesion ${ }^{2}$.

Although several studies point to the positive association between PS and team cohesion and the inverse association for $\mathrm{PC}^{2,34,35}$, researchers have pointed out the inconsistencies in these associations since perfectionism might be an individual characteristic that can enhance or prejudice cognitive, physical and motor performance ${ }^{14}$, 35. Thus, this study becomes relevant insofar as it can provide relevant information about the role of a personality trait (perfectionism) in the group process through team cohesion. The findings can be used by coaches and sports professionals to develop strategies for optimizing athletes' performance, goal setting and team work according to the their traits of PC and PS. Therefore, this research aimed to investigate the predictive role of perfectionism traits on perception of team cohesion among Brazilian futsal athletes. The proposed hypothesis is that PS will predict positively both social and task cohesion, while PC will predict team cohesion negatively.

\section{Methods}

\section{Participants}

The participants of this cross-sectional study were 140 male futsal athletes, with a mean age of $24.8 \pm$ 4.9 years, from 15 teams that participated in a Brazilian Amateur Cup in 2017. The competition is the main amateur futsal competition in the interior of the states of Pernambuco and Bahia, Brazil. Participants were selected through a non-probabilistic way and for convenience. The following inclusion criteria have been adopted: 1) be at least 18 years old; 2) be affiliated to the Cup. Exclusion criteria were not responding to all items of the questionnaires, however, none athlete was excluded from the study. Only the athletes who had the Consent Term signed were included in this study.

\section{Instruments}

Perfectionism. To identify perfectionism traits was used the Sport Multidimensional Perfectionism Scale-2
(SMPS-2) ${ }^{36}$, adapted and validated for the Brazilian context by Nascimento Junior et al. ${ }^{37}$. The instrument consists of 24 items answered on a Likert scale of five points $(1=$ completely disagree with $5=$ completely agree). The results are grouped into four sub-scales: organization-personal standards (OPS), concern over mistakes (COM), perceived parental pressure (PPP) and doubts about action (DAA). The Cronbach's Alpha varied between $\alpha=0.73$ and $\alpha=0.79$, indicating strong internal reliability ${ }^{38}$.

Team cohesion. The Group Environment Questionnaire (GEQ) ${ }^{29}$ was used to identify athletes' perception of team cohesion, as validated for the Brazilian context ${ }^{39}$. GEQ consists of 16 items, which are responded on a 9point-Likert-type scale (1- strongly disagree to 9-strongly agree), divided into four dimensions: 1) Group-Integration Task (GI-T); 2) Group-Integration Social (GI-S); 3) Individual Attraction to Group-Task (IA-T); and 4) Individual Attraction to the Group-Social (IA-S). Cronbach's Alpha varied between $\alpha=0.73$ and $\alpha=0.84$, indicating strong reliability $^{38}$.

\section{Procedures}

The study is part of an institutional project approved by the Research Ethics Committee of the Federal University of Vale do São Francisco (opinion 1.648.086). Initially, researchers contacted the competition organizer to request permission to carry out the data collection with the athletes of the participating teams of the competition. With this, teams' managers and head coaches were contacted in order to arrange dates for data collection during the beginning of the 2018 season at the teams' local training facility. It was decided to collect data in this period due to the beginning of the season the individual and team's performance not to influence too much the group environment. The questionnaire was applied individually in a private room. To avoid sources of bias in the data collection, a single evaluator applied the questionnaires. The evaluator explained how to answer the questionnaire before data collection.

\section{Data analysis}

Data analysis was conducted through descriptive and inferential statistics. Pearson Correlation was used to investigate the relationship between team cohesion and perfectionism. Multiple Regression Analysis was used to determine whether the perfectionism might predict the perception of team cohesion. Four models were conducted using the backward method to enter the variables (removal criterion $\mathrm{F}=0.10$ ) to investigate the predictive role of perfectionism subscales on scores of team cohesion dimensions (dependent variable): IA-T (Model 1); GI-T (Model 2); IA-S (Model 3) and GI-S (Model 4). All independent variables were included together in the model in the same block. Data were screened to ensure that assumptions of normality, linearity, multicollinearity, and homogeneity of 
variance-covariance matrices were $\mathrm{met}^{40}$. Data showed normal distribution and variances were equal. There were no sufficiently strong correlations between variables that indicate problems with multicollinearity (Variance Inflation Factors $<5.0$ ). All analysis was performed at SPSS v.22.0.

\section{Results}

It is noted (Table 1) that the athletes showed high scores (mean) at both task and social cohesion dimensions. In addition, a higher score for the dimension of perfectionistic striving stands out, but also a high score for COM.

Pearson correlation (Table 2) indicated the following significant correlations $(\mathrm{p}<0.05)$ : OPS with GI-T $(\mathrm{r}=$ $.27)$, GI-S $(\mathrm{r}=.18)$, IA-T $(\mathrm{r}=.25)$ and IA-S $(\mathrm{r}=.17)$; DAA with GI-T $(r=-.24)$. It is highlighted the positive association of perfectionistic striving with all dimensions

Table 1 - Descriptive values (minimum, maximum, mean, standard deviation, skewness and kurtosis) and data distribution of the variables.

\begin{tabular}{llllll}
\hline Variables & Minimum & Maximum & M (Sd) & Skewness & Kurtosis \\
\hline \multicolumn{2}{l}{ Team cohesion } & & & & \\
IA-S & 4.00 & 9.00 & $7.62(1.10)$ & -0.90 & 0.58 \\
GI-S & 1.80 & 9.00 & $6.54(1.56)$ & -0.46 & -0.11 \\
IA-T & 2.00 & 9.00 & $8.29(.93)$ & -2.91 & 1.72 \\
GI-T & 4.40 & 9.00 & $7.99(.97)$ & -1.20 & 1.19 \\
\multicolumn{2}{l}{ Perfectionism } & & & & \\
OPS & 1.00 & 6.29 & $3.92(.65)$ & 0.27 & 1.71 \\
COM & 1.00 & 7.00 & $3.14(.97)$ & 0.66 & 2.08 \\
PPP & 1.00 & 4.86 & $2.68(.79)$ & 0.13 & -0.22 \\
DAA & 1.00 & 5.00 & $2.69(.88)$ & 0.32 & -0.31 \\
\hline
\end{tabular}

Note: $\mathrm{M}=$ Mean; $\mathrm{Sd}=$ Standard deviation; IA-S = Individual Attraction to the Group-Social; GI-S = Group-Integration Social; IA-T = Individual Attraction to Group-Task; GI-T = Group-Integration Task; OPS = Organization-Personal Standards; $\mathrm{COM}=$ Concern over Mistake; PPP $=$ Perceived Parental Pressure; DAA = Doubts about action. of social and task cohesion, as well as a negative association of DAA with GI-T.

Multiple Regression Analysis (Tables 3 and 4) was used to determine the predictive role of perfectionism on scores of team cohesion. Perfectionism subscales $(\mathrm{R}=.39$; $\left.\mathrm{R}^{2}=.13 ; \mathrm{F}=6.329\right)$ showed a shared variance of $13 \%$ with GI-T, however, only OPS and DAA were significant predictors of GI-T. The association of OPS $(\beta=.33)$ with GI-T was positive, while DAA ( $\beta=-.27)$ showed a negative association. Regarding IA-T (Table 3), perfectionism subscales $\left(\mathrm{R}=.28 ; \mathrm{R}^{2}=.05 ; \mathrm{F}=3.034\right)$ explained $5 \%$ of its variance, however, only OPS showed a significant and positive $(\beta=.25)$ association with IA-T.

Table 4 demonstrates the predicting role of perfectionism subscales on scores of social cohesion dimensions. Perfectionism subscales $\left(\mathrm{R}=.29 ; \mathrm{R}^{2}=.05 ; \mathrm{F}=3.170\right)$ showed a shared variance of $5 \%$ with GI-S, however, only PPP and DAA were significant predictors of GI-S. The association of PPP $(\beta=.23)$ with GI-S was positive, while DAA $(\beta=-.21)$ showed a negative association. Regarding IAS (Table 4), perfectionism subscales $\left(\mathrm{R}=.25 ; \mathrm{R}^{2}=.03\right.$; $\mathrm{F}=2.299)$ explained $3 \%$ of its variance, however, only DAA showed a significant and negative $(\beta=-.20)$ association with IA-S.

\section{Discussion}

The results of this investigation may provide new information for future studies involving perfectionism traits and team cohesion in sports. The main findings revealed the positive predictor role of PS and negative role of PC over task cohesion (Table 3), whereas, for social cohesion, there was a negative predictor role of the PC, specifically of doubts about actions, besides a positive association with parental pressure (Table 4).

Regarding the role of perfectionism in predicting the athletes' perception of team cohesion (Tables 3 and 4), it can be observed that PS (personal standards and organization) were positively associated with both task cohesion.

Table 2 - Correlation between team cohesion and perfectionism subscales among Brazilian futsal athletes.

\begin{tabular}{|c|c|c|c|c|c|c|c|c|}
\hline \multirow{2}{*}{$\begin{array}{l}\text { Team Cohesion } \\
\text { Variables }\end{array}$} & \multicolumn{8}{|c|}{ Perfectionism } \\
\hline & $\overline{1}$ & 2 & 3 & 4 & 5 & 6 & 7 & 8 \\
\hline 1.GIT & & $0.48 * *$ & $0.51 * *$ & $0.55 * *$ & $0.27 * *$ & -0.01 & -0.03 & $-0.24 * *$ \\
\hline 2.GIS & & & $0.33 * *$ & $0.49 * *$ & $0.18 *$ & 0.03 & 0.13 & -0.11 \\
\hline 3.IAT & & & & $0.46 * *$ & $0.25 * *$ & 0.08 & 0.06 & -0.10 \\
\hline 4.IAS & & & & & $0.17 *$ & 0.05 & 0.00 & -0.16 \\
\hline 5.OPS & & & & & & $0.43 * *$ & $0.31 * *$ & 0.07 \\
\hline 6.COM & & & & & & & $0.46 * *$ & $0.21 * *$ \\
\hline 7.PPP & & & & & & & & $0.48 * *$ \\
\hline 8.DAA & & & & & & & & \\
\hline
\end{tabular}

Significant correlation: $* * p<.01 ; * \mathrm{p}<.05$. Pearson Coeficient. Note: IAS = Individual Attraction to the Group-Social; GIS = Group-Integration Social; IAT = Individual Attraction to Group-Task; GIT = Group-Integration Task; OPS = Organization-Personal Standards; COM = Concern over Mistakes; PPP $=$ Perceived Parental Pressure; DAA = Doubts about action . 
Table 3 - Multiple Regression Analysis using subscales of perfectionism as predictors of Task Cohesion.

\begin{tabular}{|c|c|c|c|c|c|c|}
\hline Predicted dimension & $\mathbf{R}$ & Adjusted $\mathbf{R}^{2}$ & $\mathbf{F}$ & B & VIF & Sig. \\
\hline \multicolumn{7}{|l|}{ GIT } \\
\hline OPS & 0.39 & 0.13 & 6.329 & 0.33 & 1.27 & $<0.001$ \\
\hline $\mathrm{COM}$ & & & & -0.12 & 1.44 & 0.203 \\
\hline PPP & & & & 0.05 & 1.63 & 0.612 \\
\hline DAA & & & & -0.27 & 1.32 & 0.003 \\
\hline \multicolumn{7}{|l|}{ IAT } \\
\hline OPS & 0.28 & 0.05 & 3.034 & 0.25 & 1.27 & 0.007 \\
\hline $\mathrm{COM}$ & & & & -0.03 & 1.44 & 0.756 \\
\hline PPP & & & & 0.07 & 1.63 & 0.454 \\
\hline DAA & & & & -0.15 & 1.32 & 0.106 \\
\hline
\end{tabular}

*Significant association $(\mathrm{p}<.05)$ Note: IAT $=$ Individual Attraction to Group-Task; GIT = Group-Integration Task (GI-T); OPS = Organization-Personal Standards; $\mathrm{COM}=$ Concern over Mistake; PPP = Perceived Parental Pressure; DAA = Doubts about action.

Table 4 - Multiple Regression Analysis using subscales of perfectionism as predictors of Social Cohesion.

\begin{tabular}{lcccccc}
\hline Predicted dimension & $\mathbf{R}$ & Adjusted $^{\mathbf{2}}$ & $\mathbf{F}$ & $\mathbf{B}$ & VIF & Sig. \\
\hline GIS & & & & & & \\
OPS & 0.29 & 0.05 & 3.170 & 0.17 & 1.27 & 0.600 \\
COM & & & & -0.10 & 1.44 & 0.315 \\
PPP & & & & .023 & 1.63 & $\mathbf{0 . 0 2 9}$ \\
DAA & & & & -0.21 & 1.32 & $\mathbf{0 . 0 2 2}$ \\
IAS & & & & & & \\
OPS & 0.25 & & & 0.16 & 1.27 & 0.077 \\
COM & & 0.03 & 2.299 & 0.00 & 1.44 & 0.945 \\
PPP & & & & 0.05 & 1.63 & 0.630 \\
DAA & & & & -0.20 & 1.32 & $\mathbf{0 . 0 3 3}$ \\
\hline
\end{tabular}

*Significant association $(\mathrm{p}<.05)$ Note: IA-S $=$ Individual Attraction to the Group-Social; GI-S = Group-Integration Social; OPS = OrganizationPersonal Standards; $\mathrm{COM}=$ Concern over Mistakes; PPP $=$ Perceived Parental Pressure; DAA = Doubts in action.

This result confirms the hypotheses that high personal standards and the constant pursuit of excellence can be considered factors associated with greater effort, determination, and interest in performing tasks, as well as greater involvement with collective goals ${ }^{2,8,11}$. PS allows athletes to interact with the social context in pursuit of personal goals $^{41}$, as athletes involve the needs for social integration and individual attraction for the group to achieve high personal standards ${ }^{42}$.

Recent studies have confirmed this hypothesis by demonstrating that PS is associated with greater social interaction as well as greater engagement with team goals $^{2,13,20,43}$. Hill et al. ${ }^{13}$ demonstrated that PS corresponds to the skill to produce a performance of quality and that the quality level of the team is measured by joining these athletes' skills. That is, higher PS can be considered a predictor of higher levels of team cohesion and, consequently, higher will be the group results over the sea$\operatorname{son}^{11,43,44}$.
Regarding PC (Tables 3 and 4), DAA was a negative predictor on task (GI-T) and social (IA-S) cohesion. It seems that when athletes are not sure about the decisionmaking during practices and matches, the collective work can be harmed by this individual characteristic ${ }^{26,30}$ as well as the attraction of each athlete to develop social interactions with team members ${ }^{30}$. Recent studies have shown that PC can affect team performance through low levels of both social and task cohesion since it is very likely that PC bring the group an individualistic dynamic, making it difficult to develop social interaction and build team goals by directly affecting group cohesion ${ }^{22,41,45}$. These factors can also be aggravated by the association of high training routines, concerns about mistakes, and technical level disparity among team members $8,10,12,44$.

The literature demonstrates that $\mathrm{PC}$ is related to various negative psychic occurrences, such as fear of failure, stress, depression, anxiety, somatic complaints, and low personal satisfaction with life, school and family $8,14,46,47$. This scenario can hinder interaction in the social context since these athletes usually isolate themselves from the rest of the group, hindering the social context of the team ${ }^{14,41}$. Pineda-Espejel et al. ${ }^{14}$ argue this situation can occur because the fear of failure is a consequence of several perceptions of criticism from close social peers (friends, coaches, teammates, family) and some athletes tend to anticipate shame and humiliation after failure ${ }^{48,49}$.

Further, it was observed (Table 4) PPP revealed to be a positive predictor of social cohesion (GI-S), indicating that parental pressure seems to enhance athletes' involvement with social relationships with teammates. This result shows that the environment conceived outside the sport (e.g. family) may favor social cohesion in sport, increasing the perception of externally controlling pressures, such as concern over mistakes and pressure from coaches ${ }^{50}$. Diverging from our results, authors have suggested that PPP in athletes may be related to various psychic episodes, 
such as fear of failure, stress, depression, anxiety, somatic complaints, low personal satisfaction, with one's own life, and family ${ }^{8,47}$.

Therefore, one of the hypotheses of this research that the PS would positively predict social cohesion has not been confirmed (see Table 4). These results corroborate with literature that indicates level higher PS it is related to performance standards, organization, and discipline $e^{2,8,11}$. Thus, these athletes participated in the main competition of amateur futsal being able to link the perfectionism and the source of personal and interpersonal difficulties. These adversities included concerns, emotional reactions (e.g. anxiety), physical experiences (e.g. sleepless nights), and poorer relationships with family, friends, and teammates $^{20,21}$.

Finally, it can be observed that the athletes presented high scores for both social and task cohesion dimensions, with a highlight for task cohesion (Table 1). Nascimento Júnior, Vieira, Souza and Vieira ${ }^{51}$ found similar results investigating team cohesion among futsal. Passos et al. ${ }^{52}$ pointed out that high-performance sports teams are, by their nature, more task-oriented, as is the case with this study. In this way, both social cohesion and the task are important factors for sports teams ${ }^{51}$.

Regarding perfectionism traits (Table 1), athletes showed high scores at PS (personal standards/organization) as well as in concerns over mistakes (PC). Athletes with high personal standards feel the need to succeed and are more intrinsically motivated to have better performance ${ }^{35}$. A high score at concern over mistakes might be related to the fact that athletes are participating in the most important competition in the context in which they are inserted, Thus, they are more afraid of making mistakes in the competition and not being able to perform well ${ }^{14,53}$. Pineda-Espejel et al. ${ }^{14}$ states this situation may be related to the fear of failure, which results in diverse perceptions of criticism from close social peers (parents, coach, teammates).

Despite the findings presented in this study, it is important to highlight some limitations. First, the sample consisted only of futsal athletes from a single Brazilian state, which makes it impossible to generalize the results with the national and international scenario. However, the athletes were participating in the region's main competition in the sport. Further, the study presented a crosssectional design, assessing the athletes in just one moment of the season, which makes it impossible to analyze the cause and effect relationships between the variables. Thus, it is suggested that future research should also be conducted with athletes of other team sports, in order to compare groups, as well as the involvement of other variables and with longitudinal design to verify the possible variance of perfectionism and team cohesion over a season.

\section{Conclusion}

Evidence suggest that in high-performance futsal context, PS seems to be a positive predictor of athletes' perception of task cohesion, while PC might predict negatively both social and task cohesion, with exception of PPP, which seems to have a positive association with social cohesion. From a practical standpoint, it is important the psychological accompaniment of athletes to help them to develop their personality traits in a positive way (adaptive perfectionism), which are associated with better team cohesion. Further, the development of athletes' confidence is crucial, as DAA seems to negatively interfere with team cohesion.

\section{References}

1. Nascimento-Júnior JRA, Granja CTL, Silva ECd, Amorim DR, Oliveira DV, Vieira LF. A frequência de jogos como titular e o tempo na equipe são fatores intervenientes na percepção de coesão de grupo no contexto do futsal de alto rendimento? Rev Insp Mov Saude. 2018;(2).

2. Nascimento J, Vissoci J, Lavallee D, Codonhato R, Nascimento Junior JVA, Vieira LF. The mediating role of basic needs satisfaction on the relationship of perfectionism traits and team cohesion among elite futsal athletes. Inter J Sport Psy. 2017;48(6):591-609.

3. Balbim GM, Nascimento Junior JRA, Vieira LF. RBCDH. Rev bras cineantropom desempenho hum. 2012;14(6):70412.

4. Passos PCB, Costa LCA, Nascimento Junior JRA, Moreira CR, Vieira LF. Futsal de alto rendimento: uma fonte de motivação autodeterminada e satisfação atlética? Rev Bra Ciê Movi. 2018;26(3):75-82.

5. Davis L, Jowett S. Coach-athlete attachment and the quality of the coach-athlete relationship: implications for athlete's well-being. J sports scie. 2014;32(15):1454-64.

6. Beauchamp MR, Jackson B, Lavallee D. Into the mix: Personality processes and group dynamics in sport teams. Group Dynamics in Exercise and Sport Psychology: Routledge; 2014. p. 21-37.

7. Oliveira Ld, Vissoci J, Nascimento Junior J, Ferreira L, Viera L, Silva P. Impacto dos traços de perfeccionismo. Rev Bras Cineantropom Desempenho Hum. 2015;17(5):601-11.

8. Stoeber J. The psychology of perfectionism: Critical issues, open questions, and future directions. 2018.

9. Saba F. Aderência: Editora Manole Ltda; 2001.

10. Stoeber J, Damian LE, Madigan DJ. Perfectionism: A Motivational Perspective. The Psychology of Perfectionism: Routledge; 2017. p. 20-44.

11. Stoeber J, Edbrooke-Childs JH, Damian LE. Dimensions of Perfectionism. 2016.

12. Stoeber J, Otto K. Positive conceptions of perfectionism: Approaches, evidence, challenges. Personality and social psychology review. 2006;10(4):295-319.

13. Hill AP, Madigan DJ, Smith MM, Mallinson-Howard SH, Donachie T. Perfectionism in Sport. 2019. 
14. Pineda-Espejel HA, Morquecho-Sánchez R, Fernández R, González-Hernández J. Perfeccionismo interpersonal, miedo a fallar, y afectos en el deporte. Cuadernos de Psicología del Deporte. 2019;19(2):115-25.

15. Jowett GE, Hill AP, Hall HK, Curran T. Perfectionism, burnout and engagement in youth sport: The mediating role of basic psychological needs. Psychology of Sport and Exercise. 2016;24:18-26.

16. Cowden RG, Crust L, Jackman PC, Duckett TR. Perfectionism and motivation in sport: The mediating role of mental toughness. South African Journal of Science. 2019;115(12):1-7.

17. Oliveira LPd, Vissoci JRN, Nascimento Junior JRAd, Ferreira L, Vieira LF, Silva PNd, et al. The impact of perfectionism traits on motivation in high-performance soccer athletes. Revista Brasileira de Cineantropometria \& Desempenho Humano. 2015;17(5):601-11.

18. Tashman LS, Tenenbaum G, Eklund R. The effect of perceived stress on the relationship between perfectionism and burnout in coaches. Anxiety, Stress, \& Coping. 2010;23 (2): 195-212.

19. Stoeber J, Otto K, Pescheck E, Becker C, Stoll O. Perfectionism and competitive anxiety in athletes: Differentiating striving for perfection and negative reactions to imperfection. Personality and Individual Differences. 2007;42 (6):959-69.

20. Hill AP, Mallinson-Howard SH, Jowett GE. Perfectionism in Sport: A meta-analytical review. Sport, Exercise, and Performance Psychology. 2018.

21. Holt NL. A person-oriented examination of perfectionism and slump-related coping in female intercollegiate volleyball players. Perfectionism In Sport And Dance. 2014;45:298-324.

22. Stoeber J. The dual nature of perfectionism in sports: Relationships with emotion, motivation, and performance. International Review of Sport and Exercise Psychology. 2011;4 (2):128-45.

23. Hafez D, Heisler M, Choi H, Ankuda CK, Winkelman T, Kullgren JT. Association between purpose in life and glucose control among older adults. Annals of Behavioral Medicine. 2018;52(4):309-18.

24. Hill AP, Mallinson-Howard SH, Jowett GE. Multidimensional perfectionism in sport: A meta-analytical review. Sport, Exercise, and Performance Psychology. 2018;7(3):235.

25. Ebstrup JF, Eplov LF, Pisinger C, Jørgensen T. Association between the Five Factor personality traits and perceived stress: is the effect mediated by general self-efficacy? Anxiety, Stress \& Coping. 2011;24(4):407-19.

26. Eys M, Bruner MW, Martin LJ. The dynamic group environment in sport and exercise. Psychology of Sport and Exercise. 2018.

27. Eys M, Evans MB, Martin LJ, Ohlert J, Wolf SA, Van Bussel $\mathrm{M}$, et al. Cohesion and performance for female and male sport teams. The Sport Psychologist. 2015;29(2):97-109.

28. Eys MA, Brawley LR. Reflections on cohesion research with sport and exercise groups. Social and Personality Psychology Compass. 2018;12(4):e12379.

29. Carron AV, Widmeyer WN, Brawley LR. The development of an instrument to assess cohesion in sport teams: The
Group Environment Questionnaire. Journal of sport psychology. 1985;7(3):244-66.

30. Carron AV, Brawley LR. Cohesion: Conceptual and measurement issues. Small Group Research. 2012;43(6):726-43.

31. Carron AV, Brawley LR, Eys MA, Bray S, Dorsch K, Estabrooks $\mathrm{P}$, et al. Do individual perceptions of group cohesion reflect shared beliefs? An empirical analysis. Small group research. 2003;34(4):468-96.

32. Leo FM, Sánchez-Miguel PA, Sánchez-Oliva D, Amado D, García-Calvo T. Analysis of cohesion and collective efficacy profiles for the performance of soccer players. Journal of human kinetics. 2013;39(1):221-9.

33. McLeod J, Von Treuer K. Towards a cohesive theory of cohesion. International Journal of Business and Social Research. 2013;3(12):1-11.

34. Fiorese Vieira L, Andrade do Nascimento Junior JR, Lopes Vieira JL. Perfeccionismo y nivel de cohesión de grupo de deportistas adultos de fútbol sala. Revista de psicología del deporte. 2013;22(2):0331-336.

35. Madigan DJ, Stoeber J, Passfield L. Motivation mediates the perfectionism-burnout relationship: A three-wave longitudinal study with junior athletes. Journal of sport and exercise psychology. 2016;38(4):341-54.

36. Gotwals JK, Dunn JG. A multi-method multi-analytic approach to establishing internal construct validity evidence: The Sport Multidimensional Perfectionism Scale 2. Measurement in Physical Education and Exercise Science. 2009;13(2):71-92.

37. Nascimento Junior JRAd, Vissoci JRN, Lavallee D, Vieira LF. Adaptation and validation of the Sport Multidimensional Perfectionism Scale-2 (SMPS-2) for the Brazilian sport context. Motriz: J. Phys. Ed. 2015;21(2):125-36.

38. Hair JF, Risher JJ, Sarstedt M, Ringle CM. When to use and how to report the results of PLS-SEM. Eur. Bus. Rev. 2019;31(1):2-24.

39. Nascimento Junior JRAd, Vieira LF, Rosado AFB, Serpa S. Validation of the Group Environment Questionnaire (GEQ) for Portuguese language. Motriz: J. Phys. Ed. 2012;18 (4):770-82.

40. Tabachnick BG, Fidell LS. Principal components and factor analysis. Using multivariate statistics. 2001;4:582-633.

41. Nascimento Junior JRAd, Silva AA, Granja CTL, Oliveira DVd, Fortes LdS. Do sporting experiences predict team cohesion in youth athletes? Do sporting experiences predict team cohesion in youth athletes? Cuadernos de Psicología del Deporte, 2019 19(3), 102-112.

42. Flett GL, Hewitt PL. The perils of perfectionism in sports and exercise. Curr. Dir. Psychol. Sci. 2005;14(1):14-8.

43. Hill AP, Witcher CS, Gotwals JK, Leyland AF. A qualitative study of perfectionism among self-identified perfectionists in sport and the performing arts. Sport Exerc. Perform. Psychol. 2015;4(4):237.

44. Stoeber J, Madigan DJ. Measuring perfectionism in sport, dance, and exercise: Review, critique, recommendations. The psychology of perfectionism in sport, dance and exercise: Routledge; 2016. p. 47-72.

45. LePine JA, Buckman BR, Crawford ER, Methot JR. A review of research on personality in teams: Accounting for 
pathways spanning levels of theory and analysis. Hum. Resour. Manag. Rev. 2011;21(4):311-30.

46. Damian LE, Negru-Subtirica O, Stoeber J, Băban A. Perfectionistic concerns predict increases in adolescents' anxiety symptoms: A three-wave longitudinal study. Anxiety, Stress, \& Coping. 2017;30(5):551-61.

47. Damian LE, Stoeber J, Negru O, Băban A. Perfectionism and achievement goal orientations in adolescent school students. Psychol. Sch. 2014;51(9):960-71.

48. Villena AJM, Hernández JG, Zafra AO. Perfeccionismo percibido y expresión de ira en deportistas varones adolescentes: Influencia sobre la autoestima. Revista Argentina de Ciencias del Comportamiento. RACC. 2016;8(3):30-9.

49. Sagar SS, Stoeber J. Perfectionism, fear of failure, and affective responses to success and failure: The central role of fear of experiencing shame and embarrassment. J SPORT EXERCISE PSY. 2009;31(5):602-27.

50. Vallerand RJ. Intrinsic and extrinsic motivation in sport and physical activity. Handbook of sport psychology. 2007;3:5983.

51. Nascimento Junior JRA, Vieira LF, Souza EA, Vieira JLL. Nível de satisfação do atleta e coesão de grupo em equipes de futsal adulto. Rev Bras Cineantropom Desempenho Hum. 2011;13(2):138-44.
52. Paes MJ, do Amaral Machado T, Berbetz SR, Stefanello JMF. Frequência, intensidade e direção da ansiedade e sua relação com a coesão grupal em uma equipe de voleibol infanto-juvenil masculina. RBPE. 2017;6(3).

53. Madigan DJ, Stoeber J, Passfield L. Perfectionism and attitudes towards doping in junior athletes. J. Sports Sci.. 2016;34(8):700-6.

\section{Corresponding author}

Gabriel Lucas Morais Freire: Universidade Federal do Vale do Sao Francisco, Educação Física, Avenida Olinda Dom Helder Camara n. 402, CEP 53010005, Olinda, PE, Brazil.

E-mail: bi88el@gmail.com.

Manuscript received on November 5, 2019

Manuscript accepted on March 17, 2020

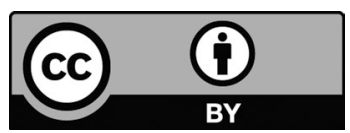

Motriz. The Journal of Physical Education. UNESP. Rio Claro, SP, Brazil - eISSN: 1980-6574 - under a license Creative Commons - Version 4.0 